\title{
Peyoteism and the Origins of Caddo Religious Thought
}

Robert Cast

Unknown

Follow this and additional works at: https://scholarworks.sfasu.edu/ita

Part of the American Material Culture Commons, Archaeological Anthropology Commons, Environmental Studies Commons, Other American Studies Commons, Other Arts and Humanities Commons, Other History of Art, Architecture, and Archaeology Commons, and the United States History Commons

Tell us how this article helped you.

This Article is brought to you for free and open access by the Center for Regional Heritage Research at SFA ScholarWorks. It has been accepted for inclusion in Index of Texas Archaeology: Open Access Gray Literature from the Lone Star State by an authorized editor of SFA ScholarWorks. For more information, please contact cdsscholarworks@sfasu.edu. 


\section{Peyoteism and the Origins of Caddo Religious Thought}

Creative Commons License

(c) (i) (8)

This work is licensed under a Creative Commons Attribution-NonCommercial 4.0 International License 


\section{Peyoteism And The ORIgins of CAddo Religious Thought}

\section{Robert Cast}

Peyote, or Lophophora williamsii, has long been a sacred medicinal plant to a number of tribes across the United States. The Caddo Indians have a distinguished and long history of using this important plant. John Swanton (1996:121) noted:

It is interesting to remember that peyote was used by medicine men among the Hasinai at the beginning of the eighteenth century, and recalling the elaborate ritualism of the Caddo, as well as their various contacts with Christian missionaries, including the presence among them of established missions for three decades, one wonders whether such a background does not constitute part of the explanation of John Wilson. It may put the ancient fire cult of the Natchez and Caddo, Franciscan teachings, the Ghost dance religion, the peyote cult, and the North American churches founded on the last mentioned in one line of descent.

The Caddo Indians practiced a vibrant peyote religion long before John Wilson (Moonhead) or Quanah Parker re-ignited the Native American Church. Moreover, research has shown the importance of the peyote plant to the Caddo long before any European contact. The peyote religion at the time of the Spanish missions in Texas was full of songs and dances in honor of one known today as (A?ah? hi-u kuu-i'-ha) or Father Above, translated to mean home where God lives. Although Swanton proposes that the Hasinai medicine men used peyote "at the beginning of the eighteenth century" (a reference to Friar Hidalgo's Spanish account) how long had they been using this plant before any written records?

In Swanton's analysis of the Caddo Indians, he recognized that during the contact period with the Spanish and the establishment of Spanish missions in east Texas that the Caddo did not convert to Catholicism as hoped, because they had a long standing tradition of worshiping their God in their own way. Although the Caddo have long been referred to as being a part of a perpetual or eternal "fire" cult "e'but ni-kuu", (literally grandfather fire) the fire was only a small part of the ritualism, the Peyote or "sik'uh-ho" (from the literal meaning "rock") has long been the central foundation for the religion.

Historian Mariah F.Wade (n.d.:10) in her translation of a November 4, 1716 letter from Fray Hidalgo to the Viceroy of New Spain recognizes this as well and emphasizes several important points in her "Introduction" to the translation: 1) The Caddo refused the religion of the Friars and the Catholic Church and, 2) That "researchers have notcompletelyunderstood the essence of this refusal nor thestrength ofCaddo religious practices and convictions." Her translation goes on to describe Friar Hidalgo's biased but pertinent viewpoints regarding the Hasinai Caddo:

As far as we have determined all this Nation is Idolater, they have houses of Adoration and they have the perpetual fire, which they do not let be extinguished. They are very superstitious, and they will believe the visions related to them by the Indian male and female who gets drunk on the peyote, or the small bean, during the Dances that they hold. They prepare this drink specifically for the celebrations... 
One interesting note is Swanton refers to the use of peyote by "medicine men" when clearly by the earliest written accounts; both men and women used peyote.

If this is the case, then where did the Caddo Indians of east Texas gather peyote?

Recently, the Caddo Nation has had a number of consultation meetings with representatives of the El Camino Real de los Tejas National Historic Trails to discuss information related to the interpretation of the trail from a Native American perspective. At one meeting hosted at the Comanche Nation Museum in Lawton, Oklahoma, several tribes were represented including the Comanche, Kiowa, and Wichita. During the meeting, each tribe voiced concerns with the trail as the National Historic Trails representatives showed them a large map of the trail explaining that the trail extended from Mexico to Nacogdoches, Texas. The Caddo voiced concerns that the route actually extended in the other direction, from Nacogdoches extending southward with branches of the trail ending up in Mexico. Several of the tribal representatives stated that they continued to use parts of this trail today to drive south to get peyote from the authorized dealers in Mexico. The irony is that the Caddo created the trail to gather their sacred plant hundreds of years earlier, with the Spanish later using the trail as a route from Mexico to explore and set-up missions in Spanish Texas.

Researchers such as Weston LaBarre, Elsie Clews Parsons, and John R. Swanton have only scantily referenced the Caddo's ancient use of peyote. More recently however, researcher Jay Miller (1996) has described the connections with the Caddo use of peyote with some the ancient stories and names within the Caddo language such as, "xinesi" also known by the Spanish as "Mr. Moon" or "Tsah Neeshi" an important cultural figure in Caddo oral history. Cecile Carter also recognized this name as most likely a mishearing of the word by the Spanish for the name of the high priest of the fire temple mound (Carter 1995).

\section{References Cited}

Carter, Cecil Elkins

1995 Caddo Indians: Where We Come From, University of Oklahoma Press

Miller, Jay

1996 Changing Moons: A History of Caddo Religion, Plains Anthropologist Vol., 41, 157, pp. 243-259.

Swanton, John R.

1996 Source Material on the History and Ethnology of the Caddo Indians. University of Oklahoma Press, Norman and London.

Wade, Mariah F.

n.d. Por Las Espaldas Se Nos Van Entrando Con Silencio: Fr. Hidalgo's Letter to the Viceroy, Article on file, University of Texas at Austin, University Extension. Thompson Conference Center. 